\title{
FERMENTASI BIJI KAKAO RAKYATMENGGUNAKAN KOTAK MODIFIKASIDENGAN VARIASI LAMA PEMERAMAN BUAH
}

\author{
Irma Laxiana dan Raden Sugiarto \\ FTP, Institut Pertanian (INTAN) Yogyakarta \\ Email: irmalaxiana@yahoo.co.id dan sugi412to@gmail.com
}

ABSTRAK

\begin{abstract}
Sampai saat ini perkakaoan Indonesia cenderung meningkat baik luas areal maupun jumlah produksi dan masih didominasi oleh Perkebunan Rakyat, namun peningkatan produksi tersebut ternyata tidak diimbangi dengan penyiapan sarana pengolahan yang memadai dan cocok untuk diterapkan di Perkebunan Rakyat. Permasalahan di tingkat internasional mutu biji kakao Indonesia adalah mutu yang masih dianggap rendah. Salah satu penyebab rendahnya mutu biji kakao Indonesia adalah keasaman relatif tinggi ( $\mathrm{pH}$ kurang dari 5,5). Tujuan penelitian ini adalah untuk mengetahui kombinasi antara pemeraman buah dengan modifikasi kotak fermentasi yang menghasilkan pH biji kakao kering 5,5. Perlakuan dalam penelitian ini: fermentasi biji kakao di dalam kotak kecil (K), fermentasi biji kakaodiantara kotak dalam dan kotak luar (A), dan fermentasi dalam kotak tanpa sekat (B). Yangdikombinasikan dengan pemeraman buah dengan variasi lama pemeraman; o hari (Ho); 4 hari ( $\left.\mathrm{H}_{4}\right)$ dan 6 hari (H6). Rancangan dalam penelitian ini menggunakan metode Rancangan Acak Lengkap (RAL) faktorial, dengan 3 kali ulangan yang berarti ada 27 unit percobaan

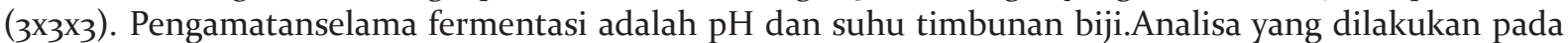
biji kakao kering:kadar air,pH, indeks fermentasi dan nilai uji-belah.Data yang diperoleh ditabulasi dan dianalisis varian. Jika terjadi perbedaan nyata dengan selang kepercayaan $5 \%$ dilanjutkan dengan Uji Duncan's Multiple Range Test. Hasil penelitian menunjukkan perlakuan pemeraman buah 4 hari dalam kotak antara (A)menghasilkan biji kakao kering dengan $\mathrm{pH}$ berkisar 5,5 dan kadar air 7,5\% yang sesuai StandarMutu (SNI: 2323:2008) yang ditetapkan.
\end{abstract}

Kata kunci : fermentasi;kakao;pemeraman buah

\begin{abstract}
Until now the Indonesian cocoa tends to increase both the total area and total production is still dominated by the Smallholder, but the increase in production was not matched by adequate preparation and processing facilities suitable to be applied in Smallholder. The problems at the international levelof Indonesian cocoa quality is still considered low quality. One of the low quality of Indonesian cocoa beans are relatively high acidity ( $\mathrm{pH}$ less than 5.5). The purpose of this study was to determine the combnatio of fruit ripening wth a fermentation box modification which produced a $\mathrm{pH}$ of dry cocoa beans 5,5. Treatment box fermentation of cocoa beans in small boxes (K), fermented cocoa beans between the box and the outer box in (A), and fermentation ina box without a bulkhead (B); ripening fruit with a long ripening variation; o day (Ho), 4 days $\left(\mathrm{H}_{4}\right)$ and 6 days (H6). The design of this research using completely randomized design (CRD) factorial, with 3 replications.Observations during the fermentation $\mathrm{p} H$ and temperatureof heapbeans. Analysis performed on dry beans fermented: waterconntent; $p H$; fermentationindex and cut tes. The data obtained were tabulated and analyzed variants. If there is a real difference with a $5 \%$ confidence interval test followed by Duncan 's Multiple Range Test.The results showed treatment of fruit ripening 4 days in a Box (A) produce dry beans with a pH range of 5.5 ; Fermentation Index of 1.39 and $7.5 \%$ Moisture appropriate Quality Standards (SNI: 2323:2008) that determined.
\end{abstract}

Keywords: cocoa, fermentation, ripening fruit. 


\section{PENDAHULUAN}

Kakao merupakan komoditi unggulan perkebunan dan berperan penting sebagai sumber devisa negara, sumber pendapatan petani,penciptaan lapangan kerja, mendorong agribisnis dan agroindustri serta pengembangan wilayah. Sampai saat ini perkakaoan Indonesia cenderung meningkat, baik luas areal maupun jumlah produksi yang masih didominasi oleh Perkebunan Rakyat. Perkiraan pada tahun 2016 : luas tanaman kakao rakyat mencapai 1.680.092 Ha dengan produksi sebesar 730.172 ton yang merupakan $97,5 \%$ dari perkebunan Kakao Indonesia (Dit Jend. Perkebunan,2015). Ini berarti bahwa perkakaoan Indonesia sangat ditentukan oleh Kakao Rakyat, namun peningkatan produksi tersebut ternyata tidak diimbangi dengan penyiapan sarana pengolahan yang memadai dan cocok untuk diterapkan di Perkebunan Rakyat. Permasalahan yang kedua adalah mutu biji kakao Indonesia adalah mutu yang masih dianggap rendah. Salah satu penyebab rendahnya mutu biji kakao Indonesia adalah keasaman relatif tinggi atau $\mathrm{pH}$ dibawah 5,1. Biji kakao dengan keasaman tinggi akan menghasilkan cita rasa cokelat yang lemah (Alamsyah,1991).

Masih rendahnya kesadaran petani kakao melakukan proses fermentasi karena jumlah panen buahnya relatif kecil, sehingga diperlukan kotak fermentasi dengan skala petani. Pengaturan kelembaban dan pengaturan suhu optimal menjadi salah satu kelemahan dalam pengolahan kakao skala kecil. Salah satu upaya yang dapat dilakukan adalah dengan rancang bangun kotak fermentasi sebagai bentuk modifikasi pengolahan biji kakao ditingkat petani yang mudah diterapkan dan relatif hemat biaya. Perlakuan pada penelitian ini adalah modifikasi kotak fermentasi skala kecil dikombinasikan dengan pemeraman buah kakao sebagai upaya mengatasi keasaman biji kakao kering yang tinggi.

\section{KAJIAN PUSTAKA}

Pengolahan biiji kakao bertujuan untuk menghasilkan biji kakao kering yang terfermentasi sempurna, keping biji berwarna coklat, berbau asam, tidak terdapat biji ungu dan slaty bean ketika biji dibelah, cangkang berwarna coklat kemerahan dan tidak pecah, bentuk biji tidak pipih dan ukuran biji seragam (Badan Pengkajian Teknologi Pertanian Lampung, 2008)

Perlakuan pemeraman buah sebelum pemecahan buah akan memberikan keuntungan pada citarasa cokelat. Menurut Duncanet al (1989), tanpa pemeraman buah akan menghasilkancitarasa cokelat yang lemah, sedangkan rasa asam, pahit dan sepetnya lebih dominan. Perlakuan pemeraman buah selama 5 hari akan menaikkan citarasa cokelat, menurunkan rasa asam, pahit dan sepet. Hal ini dapat terjadi karena pemeraman buah kakao menyebabkan pengurangan kandunganpulpyang melapisi biji sehinggaakan meningkatkan aerasi (Biehl et al 1989). Menurut Meyer et al (1989) buah yang diperam tidak mengalami fase anaerobik ketika fermentasi sehingga akan mencapai suhu tinggi dalam waktu yang lebih pendek dengan keasaman yang tidak terlalu rendah, dibanding buah yang tidak mengalami pemeraman lebih dahulu.

Kendala dalam pemeraman buah, kemungkinan terjadi pembusukan buah karena pertumbuhan jamur, kemungkinan yang lain yaitu terjadi perkecambahan biji. Data dari penelitian Yusianto dan Wahyudi(1991), serangan jamur terjadi mulai pemeraman 7 hari, dan pada pemeraman selama 10 hari terjadi serangan jamur yang menyebabkan sekitar $15 \%$ sampai 38\% biji berwarna hitam, berdasarkan data tersebut maka pemeraman buah sebaiknya dilakukan kurang dari 7 hari.

Hasil fermentasi sangat menentukan kualitas biji kakao kering, karena pada tahap ini diharapkan dapat terjadi maserasi pulp, sehingga pulp mudah dipisahkan dari biji. Tujuan lain dari fermentasi adalah terbentuknya asam asetat sebagai hasil perombakan gula dalam pulp, yang bersifat mampu mematikan biji. Biji mati akan terjadi kehilangan integritas seluler, menghasilkan tercampurnya antara substrat dan enzim sebagai reaksi yang terpenting untuk menghasilkan prekursor flavourcokelat (Lehrian dan Patterson,1983).

Selama fermentasi dilakukan kondisi anaerob dilanjutkan kondisi aerob. Kondisi 
anaerob dikendalikan dengan penutupan timbunan biji kakao yang difermentasi, sedangkan kondisi aerob dikendalikan dengan pemberian lubang-lubang pada wadah fermentasi, pengadukan dan fermentasi dalam keadaan terbuka,setiap tahap fermentasi tersebut paling lama 2 hari. Lama fermentasi diupayakan 4 atau 5 hari, kurang dari 4 hari hasil biji kakao kering kurang terfermentasi (slaty bean) yang menghasilkan rasa sangat sepet dan pahit, sedang bila berlebihan atau lebih dari 5 hari akan menghasilkan biji yang berasa hambar (Wood dan Lass, 1985). Peruraian pulpdiharapkan terjadi selama fermentasi, hal ini karena enzim pektinase berperan memecah pektin dalam pulp sehingga viskositas pulp menurun, selanjutnya akan memudahkan pelepasan pulp dari kulit biji kakao (Schwanet al 2004). Enzim pektinolitik tidak hanya dihasilkan oleh yeast tetapi juga oleh Bacillus (Ouattara et al20o8)

Diharapkan $\mathrm{pH}$ dan suhu fermentasi akan mengaktifkan enzim-enzim yang diperlukan untuk pembentukan karakterisik cokelat yaitu flavour, aroma dan warna setelah diroasting. $\mathrm{pH}$ aktivitas enzim bervariasi, seperti protease optimum pada pH 3.5 (Biehlet al1993); karboxypeptidase optimum aktivitasnya pada $\mathrm{pH}$ 5.8, aminopeptidase berkisar 6.8 (Voight et al1994; Bytofet al1995). Aktivitas enzim poliphenol oksidase terjadi pada $\mathrm{pH} 6$ dengan suhu $35,5^{\circ} \mathrm{C}$ (Lopesz dan Dimick,1991).Enzim ini berperan dalam pembentukan warna coklat yang stabil karena pembentukan quinon (Reeves et al1988). Reduksi poliphenol dibutuhkan untuk pembentukan flavour yang bagus, karena poliphenol menyebabkan rasa pahit dan sepet (Afoakwaet al2010). Untuk mendapatkan cita rasa cokelat yang kuat dituntut $\mathrm{pH}$ biji kakao kering berkisar 5,5 (Biehlet al 1989). Hal ini dapat dipahami karena aktivitas optimum enzim penentu pengembangan cita rasa cokelat pada pH sekitar 5,5-6,8 (Hansenet al 1998). Beberapa penelitian sudah dilakukan untuk mengatasi masalah fermentasi yang diperuntukkan mengatasi masalah kakao Indonesia ini, antara lain seperti perlakuan pemeraman buah sebelum fermentasi, peningkatan aerasi dengan penambahan lubang pada kotak fermentasi, mempersingkat waktu fermentasi dengan penambahan ragi.

\section{Tujuan penelitian}

Mengetahui kombinasi perlakuan yang tepat antara jenis kotak modifikasi dengan lama pemeraman buah kakao untuk menghasilkan pH biji kakao kering yang tinggi pada produksi skala kecil (Perkebunan Kakao Rakyat).

\section{METODE PENELITIAN}

\section{Tempat dan waktupenelitian}

Penelitian ini dilaksanakan di Laboratorium Kimia dan Laboratorium Teknologi Pertanian Institut Pertanian INTAN Yogyakarta. Penelitian dilaksanakanselama 5 bulan.

\section{Alat dan bahan penelitian}

Alat-alat yang digunakan adalah 3 macam kotak fermentasi modifikasi (Gambar 1) , timbangan, bekerglass, gelas ukur, corong pemisah, pengaduk, kompor listrik, oven, spektrofotometri,cutter, $\mathrm{pH}$ meter, Cabinet Dryer.

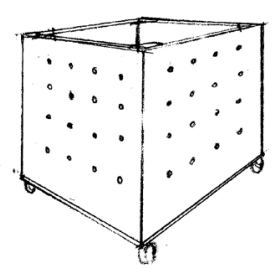

a. Kotak besar

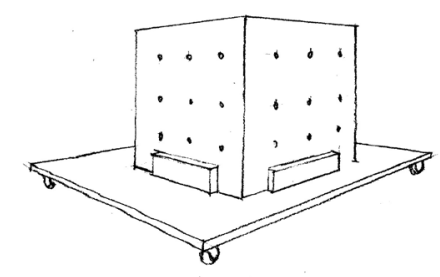

b. Kotak kecil

Gambar 1.Kotak fermentasi modifikasi

\section{Spesifikasi Kotak}

Kotak luar (besar) : (40x40x40cm).

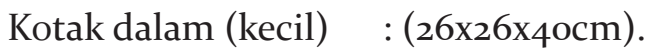

Luban gaerasi : diameter: $10 \mathrm{~mm}$; Jarak antar lubang: $80 \mathrm{~mm}$. 
Bahan penelitian adalah buah kakao dari perkebunan rakyat wilayah kecamatan Karangmojo Kabupaten Gunung KidulDaerah Istimewa Yogyakarta.

\section{Rancangan Percobaan}

Rancangan dalam penelitian ini menggunakan metode Rancangan Acak Lengkap (RAL) faktorial. Faktor I (3 faktor) adalah fermentasi biji kakao di dalam kotak kecil (K), fermentasi biji kakao diantara kotak dalam dan kotak luar (A), dan fermentasi dalam kotak tanpa sekat atau kotak besar (B). Faktor kedua (3 faktor)adalah dilakukan tanpa pemeraman buah (Ho), pemeraman buah selama 4 hari $\left(\mathrm{H}_{4}\right)$ dan 6 hari (H6). Sehingga terdapat9 kombinasi perlakuan, masing- masing perlakuan diulang 3 kali. Data yang diperoleh ditabulasi dan dianalisis varian. Jika terjadi perbedaan nyata dengan selang kepercayaan 5\%dilanjutkan dengan Uji Duncan's Multiple Range Test( Gazpers, 1994 ).

Parameter yang diamati selama 4 hari fermentasi:

1) $\mathrm{pH}$ biji kakao basah setiap 24 jam fermentasi

2) Suhu didalam timbunan biji setiap 24 jam fermentasi

Parameter yang diamati pada biji kakao kering :

1) Analisa Kadar Air (SNI o1-2323-2008)

2) Analisa Keasaman Keping Biji (SNI 2323: 2008)

3) Uji-Belah(Wahyudi,T. dan Gracia Bailon,1991)

4) Indeks Fermentasi (Wahyudi,T. dan Gracia Bailon, 1991)

\section{Tahapan Penelitian}

1. Buah kakao tanpa pemeraman dipecah, diambil bijinya sebanyak $30 \mathrm{~kg}$ dimasukkan ke kotak besar, kotak kecil dan kotak antara (antara kotak besar dan kotak kecil), setiap kotak diisi $10 \mathrm{~kg}$ biji basah, selanjutnya dilakukan fermentasi.

2. Buah kakao setelah diperam 4 hari, kemudian dipecah selanjutnya diberlakukan samaseperti tanpa pemeraman

3. Buah kakao setelah diperam 6 hari, kemudian dipecah selanjutnya diberlakukan sama seperti tanpa pemeraman

4. Fermentasi dilakukan selama 4 hari, 2 hari pertama dalam kondisi ditutup, 2 hari berikutnya dalam kondisi terbuka. Setiap 24 jam fermentasi dilakukan pengukuran $\mathrm{pH}$ biji, suhu timbunan biji dan pengadukan.

5. Pada hari ke 5 dilakukan pencucian, selanjutnya dilakukan pengeringan (penjemuran dilanjutkan menggunakan Cabinet Dryer).

6. Biji kakao kering yang dihasilkan dianalisa kadarair, keasaman keping biji, Uji-Belah dan Indeks Fermentasi.

\section{HASIL DAN PEMBAHASAN}

Hasil pengukuran suhu (Gambar 2) dan $\mathrm{pH}$ (Gambar3) selama fermentasi (4 hari) sebagai berikut:

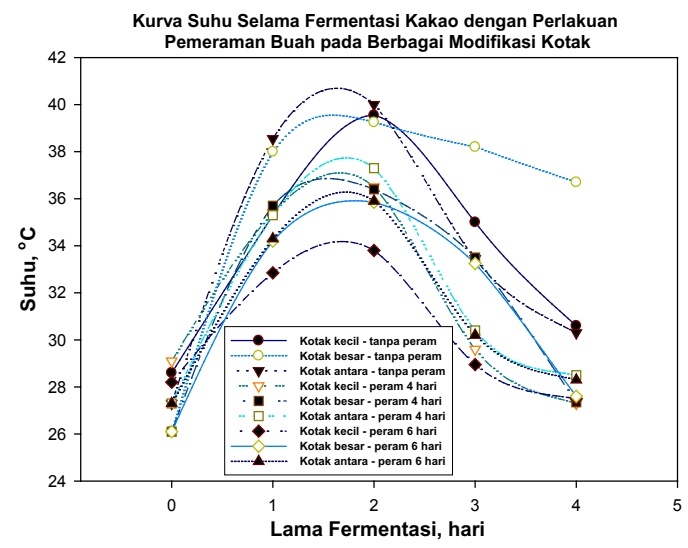

Gambar 2. Kurva Suhu selama fermentasi kakao dengan perlakuan pemeraman buah pada berbagai kotak modifikasi

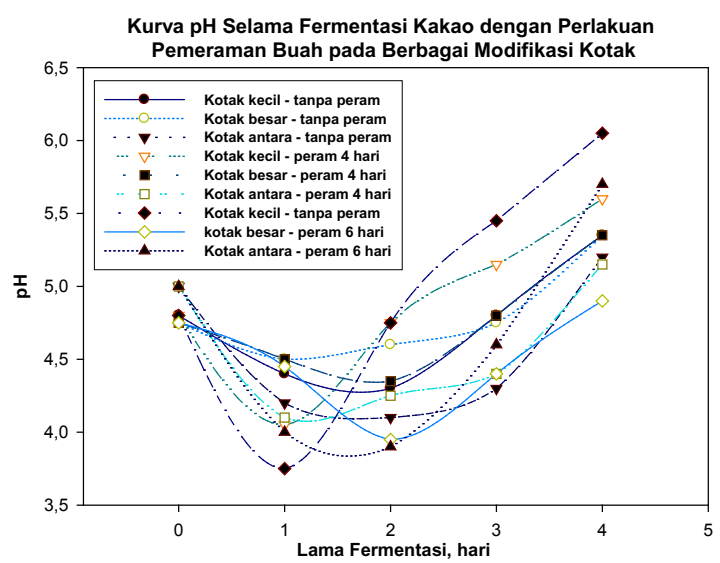

Gambar 3. Kurva pH selama fermentasi kakao dengan perlakuan pemeraman buah pada berbagai kotak modifikasi. 
Pada Gambar 2. Tinjauan untuk suhu selama fermentasi berlangsung pada berbagai jenis kotak fermentasi, dapat dilihat suhu tertinggi dicapai pada 48 jam fermentasi pada semua jenis kotak, namun yang tertinggi dicapai pada kotak kecil, dan yang terendah pada kotak antara, hal ini dapat dipahami karena dengan jumlah isian biji kakao yang sama, akan berbeda ketinggian isian pada masing-masing kotak. Isian yang tertinggi akanmengakumulasi panas hasil fermentasi lebih besar, kenaikkan suhu yang terendah terjadi pada kotak antara, hal ini dimungkinkan karena aerasi lebih besar dibanding jenis kotak yang lain.

Kenaikkan suhu yang tinggi dalam fermentasi biji kakao dengan kombinasi pHyang rendah sangat diharapkan dalam fermentasi agar tujuan fermentasi mematikan biji karena terjadi perusakan sistem seluler dapat dicapai, disamping untuk mengaktifkan enzim-enzim yang berperan dalam pembentukan prekursor flavour. Dalam hal ini untuk buah kakao tanpa pemeraman dipilih kotak kecil.Kenaikkan suhu fermentasi terlihat pada 24 jam fermentasi, kotak besar dan kotak antara relatif bertahan sampai 48 jam fermentasi, sedangkan untuk kotak kecil lebih tinggi kenaikkannya dan bertahan sampai 72 jam fermentasi. Berbeda dengan perlakuan tanpa pemeraman buah, yang menunjukkan penurunan suhu setelah 48 jam fermentasi cenderung tajam. Perlakuan pemeraman buah 4 hari berdasar kenaikkan suhu dan penurunan $\mathrm{pH}$ dipilih kotak antara. Seperti pada perlakuan pemeraman buah 4 hari, perlakuan pemeraman buah 6 hari $\mathrm{pH}$ terendah selama fermentasi dicapai setelah 48 jam fermentasi, demikian juga pencapaian suhu tertinggi selama fermentasi berlangsung. $\mathrm{pH}$ terendah 3,9 pada kotak antara, dan suhu tertinggi $40^{\circ} \mathrm{C}$ pada kotak kecil (Gambar 3).

Suhu yang lebih tinggi pada perlakuan pemeraman buah dapat terjadi karena kesiapan mikrobia, khususnya yeast untuk merombak glukosa menjadi etanol yang bersifat eksothermis.

Hasil analisa pada biji kakao kering hasil perlakuan kombinasi antara kotak modifikasi dengan lama pemeraman buah kakao dapat dilihat pada Tabel 1.

Tabel 1. pH biji kakao kering, Kadar Air (\%) dan Indeks Fermentasi (IF) kombinasi perlakuan kotak modifikasi dan lama pemeraman buah kakao.

\begin{tabular}{|c|c|c|c|c|}
\hline JENIS KOTAK & $\begin{array}{c}\text { LAMA PEMERAMAN } \\
\text { BUAH (HARI) }\end{array}$ & $\mathrm{pH}$ & $\begin{array}{l}\text { K.A } \\
(\%)\end{array}$ & IF \\
\hline \multirow{3}{*}{ Kotak Kecil } & $\mathrm{o}$ & $6,0^{a}$ & $4,74^{\mathrm{h}}$ & $1,24^{\mathrm{abc}}$ \\
\hline & 4 & $5,3^{\mathrm{b}}$ & $7,46^{\text {def }}$ & $1,51^{\mathrm{a}}$ \\
\hline & 6 & $6,05^{\mathrm{a}}$ & $10,48^{a}$ & $1,37^{\mathrm{ab}}$ \\
\hline \multirow{3}{*}{ Kotak Besar } & $\mathrm{o}$ & $6,4^{\mathrm{a}}$ & $5,70^{g}$ & $1,26^{\mathrm{abc}}$ \\
\hline & 4 & $5,3^{\mathrm{b}}$ & $7,46^{\text {def }}$ & $1,35^{\mathrm{ab}}$ \\
\hline & 6 & $5,9^{a}$ & $9,35^{\mathrm{bc}}$ & $1,41^{\mathrm{a}}$ \\
\hline \multirow{3}{*}{ Kotak Antara } & 0 & $6,45^{\mathrm{a}}$ & $4,46^{\text {hi }}$ & $1,27^{\mathrm{abc}}$ \\
\hline & 4 & $5,55^{\mathrm{a}}$ & $7,97^{d}$ & $1,39^{\mathrm{ab}}$ \\
\hline & 6 & $6,05^{\mathrm{a}}$ & $9,40^{b}$ & $1,37^{\mathrm{ab}}$ \\
\hline
\end{tabular}

*) huruf yang sama dibelakang angka dalam kolom yang sama tidak beda nyata

Tabel 1 menunjukkan $\mathrm{pH}$ yang sama untuk perlakuan pemeraman buah 4 hari pada semua jenis kotak yaitu $\mathrm{pH}$ berkisar 5,5 namun berbeda untuk perlakuan tanpa pemeraman buah dan pemeraman buah 6 hari yang relatif lebih tinggi yaitu $\mathrm{pH}$ berkisar 6,o. Berdasar $\mathrm{pH}$ yang dikehendaki untuk memperoleh citarasa cokelat yang diinginkan yaitu berkisar 5,5 atau lebih, maka pemeraman buah selama 4 hari dilakukan diberbagai jenis kotak kurang sesuai untuk tujuan tersebut kecuali jenis kotak antara yang memiliki aerasi lebih banyak dibanding 2 jenis kotak yang lain.

Kecenderungan semakin lama pemeraman 
buah semakin tinggi kadar airnya, ini terjadi untuk semua jenis kotak. Ditinjau dari kadar air biji kakao kering maksimum 7,5\% (SNI o1 - 2323 - 1991), dapat dikatakan perlakuan pemeraman buah selama 4 hari memenuhi standar biji kakao kering, sedang pemeraman buah selama 6 hari kadar air biji kakao kering terlalu tinggi, sebaliknya tanpa pemeraman buah menghasilkan kadar air terlalu rendah.

Secara keseluruhan kombinasi perlakuan pemeraman buah dan jenis kotak fermentasi menghasilkan indeks fermentasi lebih dari 1, hal ini berarti fermentasi telah mencukupi untuk mendegradasi pigmen antosianin. Antosianin yang memberikan warna ungu pada biji kakao yang belum difermentasi, selama fermentasi antosianin dihidrolisa menjadi sianidin dan gula sehingga warna ungu hilang dan akan muncul warna coklat (Wood,1975). Ditinjau dari perlakuan pemeraman buah, indeks fermentasi cenderung lebih tinggi dibanding tanpa pemeraman, kondisi ini berlaku untuk semua jenis kotak fermentasi.

Hasil rata-rata nilai Uji-Belah biji kakao kering merupakan parameter untuk mengukur tingkat keberhasilan fermentasi dengan cara membelah keping biji sebanyak zoo biji, setiap 100 biji diamati warna secara visual dan diberi nilai berdasar pedoman Nilai Uji-Belah biji kakao. Berikut Tabel 2 hasil penilaian warna Uji belah biji kakao kering:

Tabel 2. Rata-rata Nilai Uji Belah biji kakao kering pada perlakuankotak modifikasi dan lama pemeraman buah kakao.

\begin{tabular}{|c|c|c|c|c|c|c|c|}
\hline \multirow{3}{*}{ JENIS KOTAK } & \multirow{3}{*}{$\begin{array}{c}\text { LAMA } \\
\text { PEMERAMAN } \\
\text { BUAH (hari) }\end{array}$} & \multicolumn{6}{|c|}{ RATA-RATA NILAI UJI BELAH (\%) } \\
\hline & & $(1)$ & $(2)$ & (3) & (4) & (5) & (6) \\
\hline & & $\begin{array}{l}\text { Slaty } \\
\text { bean }\end{array}$ & $\begin{array}{c}\text { Keping biji } \\
\text { berwarna } \\
\text { ungu merata }\end{array}$ & $\begin{array}{c}3 / 4 \text { bag. keping } \\
\text { biji berwarna } \\
\text { ungu }\end{array}$ & $\begin{array}{c}\text { 1/2 bag. keping } \\
\text { biji berwarna } \\
\text { coklat }\end{array}$ & $\begin{array}{c}\text { 3/4 bag. keping } \\
\text { biji berwarna } \\
\text { coklat }\end{array}$ & $\begin{array}{c}\text { Keping biji } \\
\text { berwarna } \\
\text { coklat merata }\end{array}$ \\
\hline \multirow{3}{*}{ Kotak Kecil } & o & 7 & 11 & 31 & 24 & 16 & 11 \\
\hline & 4 & 6 & 8 & 28 & 32 & 25 & 1 \\
\hline & 6 & 8 & 3 & 13 & 23 & 25 & 28 \\
\hline \multirow{3}{*}{ Kotak Besar } & o & 13 & 18 & 20 & 20 & 18 & 11 \\
\hline & 4 & 9 & 11 & 20 & 30 & 22 & 8 \\
\hline & 6 & 5 & o & 10 & 15 & 27 & 43 \\
\hline \multirow{3}{*}{ Kotak Antara } & o & 4 & 4 & 13 & 22 & 32 & 25 \\
\hline & 4 & 9 & 8 & 19 & 34 & 24 & 6 \\
\hline & 6 & 10 & o & 11 & 14 & 23 & 42 \\
\hline
\end{tabular}

Nilai Uji Belah menunjukkan dengan perlakuan pemeraman buah menaikkan prosentase biji kakao terfermentasi sempurna, hal ini sejalan dengan angka Indeks Fermentasi. Dalam hal ini dipilih pemeraman buah 6 hari untuk semua jenis kotak fermentasi.

\section{KESIMPULAN}

Selama fermentasi suhu pada kotak kecil mencapai $40^{\circ} \mathrm{C}$ baik tanpa pemeraman buah maupun dengan perlakuan pemeraman buah, namun $\mathrm{pH}$ terlalu rendah. Hasil penelitian menunjukkan jenis kotak tidak mempengaruhi $\mathrm{pH}$; kadar air dan Indeks Fermentasi biji kakao kering, sedangkan perlakuan pemeraman buah hanya berpengaruh pada kadar air yang cenderung lebih tinggi.Hasil penilaian warna Uji-Belah dan Indeks Fermentasi perlakuan pemeraman buah 6 hari menghasilkan biji kakao terfermentasi sempurna, namun kadar air biji yang dihasilkan melebihi standar yang ditentukan.Dengan demikian dapat disimpulkan pemeraman buah selama 4 hari dengan fermentasi pada kotak antara lebih memenuhi kriteria mutu biji kakao kering terfermentasi dibanding perlakunan yang lain.

\section{DAFTAR PUSTAKA}

Afoakwa E.O.2010.Chocolate Science and Technology.Wilay-Blackwell Pubshers. Oxford UK Pp 3-22

Alamsyah,1991.Peranan Fermentasi dalam 
Pengolahan Biji Kakao. Berita Penelitian Perkebunan 1 (2): 97-103

Badan Standardisasi Nasional Indonesia, 2008. Biji Kakao SNI 2323-2008. Jakarta.Badan Standarisasi Nasional.

Balai Pengkajian Teknologi Pertanian Lampung, 2008. Kualitas Kakao. Askindo Propinsi Lampung.

Biehl,B. Meyer, B. Crone, G. And Pollman,L.,1989. Chemical and Physical changes in the Pulp during ripening and Postharvest Storage of Cacao Pods. J.Sci.Food Agric.48: 189-208.

Biehl,B., Voight J., Heincichs.H., Senjuk,V., Bytof, G., 1993. pH dependent enzymatic formation of oligopeptides and amino acids, the aroma precursors in raw cocoa beans. In:Lafforest $j$. (ed) Xith Intenational Cocoa research conferen. Cocoa Producers' Alliance : Yamassoukro. Ivory Coast. Pp. 717-722.

Bytof G., Biehl.B., Heinriches H. Voight J., 1995. Spesificity and Stability of the Carboxypeptidase activity. In ripe, ungerminated seeds of Theobroma cacao L. Food chemistry 54. 15-21

Direktorat Jenderal Perkebunan, 2015. Statistik Perkebunan Indonesia Komoditas Kakao 2014-2016. Direktorat Jenderal Perkebunan.

Duncan, R.J.E., Godrey. G., Yap.T.N. Pettiher,. G.L, and Tharumarajah,T., 1989. Improvement of Malaysia Cocoa Bean Flavor by Modification of Harvesting, Fermentation and Dryng Methods-The Sime Cadbury Process. Planter 69:157 Gaspersz, V. 1994. Metode Perancangan Percobaan. CV. Armico, Bandung. Hansen,C.E.. Olmo, M.D. dan Burri,C.,1998. Enzyme Activities in Cocoa Beans during Fermentation. J.Sci.Food. Agric.79.273-281.

Lehrian,D.W.and Patterson,G.R.,1983. Cocoa Fermentation. In Reed G. (Ed.) Biotechnology Vol.5. Verlag Chemie. Weinhim.Deerfield Beach, Florida.
Lopez A.S. and Dimick, 1991. Enzymes involved in cocoa curing. In Food Enzymology (Vol.1) ed. Fox P.F. Elsevier Science Publisher Ltd. London.UK. pp 211-236 Meyer ,B.and Biehl,B.,1989. Post Harvest Pod Storage : A Method for pulp preconditioning to impair strong nib acidiflestion during cocoa fermentation in Malaysia. J.Sci Food Agric. (48) (3): 285-304.

Ouattara H.G.' Keffi, B.L. Karou G.T. Abdourahamane S., Sebastian L. Niamke. Dopoh J.K 2008. Implication of Bacillus $s p$. In the production of pectinolytic enzymes during cocoa fermentation. World Journal of Microbiology and Biotechnology 24 : 1753-176o.

Reeves S G, Mc Dowell I, Behn K, Dench J, 1988. Biochemical studies of cocoa bean o-diphenol $\mathrm{O}_{2}$ oxidoreductase (catechol oxidase). Food Chem 29 : 209-219.

Schwan R.F. and Wheals A.E.,2004. The microbiology of Cocoa fermentation and its role in Chocolate quality.Crit.Rev. Food Sci Nutr.44.205-221.

Voight J., Biehl.B., Heinrichs.H.,Kamaruddin S. Gain Marsoner G., Hugi.A., 1994. Invitro formation of cocoa spesific aroma precursors; aroma related peptides generated from Cocoa seed protein by co-operation of an aspartic endoprotease and a carboxypeptidase. Food Chem. 49 : 173-180.

Wahyudi, T. dan Gracia Bailon,1991. Assesment Methodology to Predict Quality of Cocoa Beans for Export. Research Associate Asian Institute of Technology Bangkok, Thailand.

Wood, G.A.R., andR.A Lass,.1985.Cocoa.

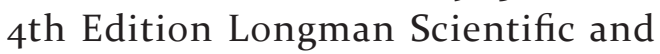
Technical. New York.

Yusianto dan Teguh-Wahyudi (1991), Pengolahan Kakao Mulia dengan metode SimeCadbury.Pengaruh Lama Penyimpanan Buah, Lama Fermentasi dan Sifat Fisiko Kimia Biji. Pelita Pekebunan 7 (2): 48-56. 